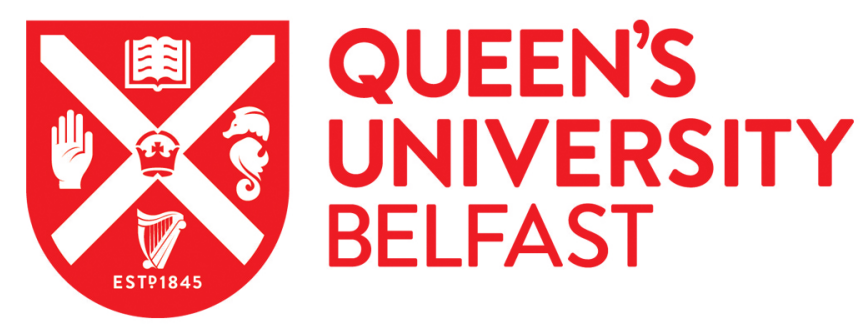

\title{
A mechanical, high surface area and solvent-free 'powder-to- electrode' fabrication method for screening OER catalysts
}

Browne, M., O'Rourke, C., \& Mills, A. (2017). A mechanical, high surface area and solvent-free 'powder-toelectrode' fabrication method for screening OER catalysts. Electrochemistry Communications, 85, 1-5. https://doi.org/10.1016/j.elecom.2017.10.011

Published in:

Electrochemistry Communications

Document Version:

Peer reviewed version

Queen's University Belfast - Research Portal:

Link to publication record in Queen's University Belfast Research Portal

\section{Publisher rights}

Copyright 2017 Elsevier.

This manuscript is distributed under a Creative Commons Attribution-NonCommercial-NoDerivs License

(https://creativecommons.org/licenses/by-nc-nd/4.0/), which permits distribution and reproduction for non-commercial purposes, provided the author and source are cited.

\section{General rights}

Copyright for the publications made accessible via the Queen's University Belfast Research Portal is retained by the author(s) and / or other copyright owners and it is a condition of accessing these publications that users recognise and abide by the legal requirements associated with these rights.

\section{Take down policy}

The Research Portal is Queen's institutional repository that provides access to Queen's research output. Every effort has been made to ensure that content in the Research Portal does not infringe any person's rights, or applicable UK laws. If you discover content in the

Research Portal that you believe breaches copyright or violates any law, please contact openaccess@qub.ac.uk. 


\title{
A Mechanical, High Surface Area and Solvent-Free 'Powder-to-Electrode' Fabrication Method for Screening OER Catalysts
}

\author{
M. P. Browne*, a C. O'Rourke ${ }^{a}$ and A. Mills ${ }^{a}$
}

a) School of Chemistry and Chemical Engineering, Queens University Belfast, UK.

Email: M.browne@qub.ac.uk

Keywords: OER, powder, electrocataysts, PTFE, pressed-disc.

\begin{abstract}
The screening of new OER materials routinely involves fabricating electrodes from powders using methods which are often time consuming and may involve using solvents and/or conductive materials that can alter the OER activity of the powder. Herein, a new mechanical, solvent-free method for fabricating electrodes for OER is described in which a electroactive material under test, mixed with a small amount of PTFE powder (ca. $10 \mathrm{wt} \%$ ), is pressed onto Pt powder to create a permanent, robust electrode that can be used in a rotating disc electrode set-up. This new method of fabricating electrodes is compared to the well-known dropcast on Glassy Carbon (GC) method, using commercially available materials: $\mathrm{RuO}_{2}, \mathrm{CO}_{3} \mathrm{O}_{4}$ and $\mathrm{NiO}$. The results show that the mechanical route produces much better OER performances, in terms of overpotential and stability, for the commercial metal oxide on the pressed discs when compared to the dropcast GC method. Finally, it is shown that this mechanical, high surface area, solvent-free electrode fabrication technique can also be achieved using silver, rather than platinum, as the conducting, support material.
\end{abstract}




\section{Introduction}

In recent years the optimisation of OER materials has been a particular focus of research among the scientific community as part of a sustained effort to build an efficient, low cost, stable solar-driven water splitting system.[1-9] The best known OER catalysts are the platinum group metal (PGM) oxides, $\mathrm{RuO}_{2}$ and $\mathrm{IrO}_{2}$ which exhibit overpotentials at $10 \mathrm{~mA} \mathrm{~cm}{ }^{-2}[5,10]$ however, these materials are rare and expensive. As a consequence, the majority of the OER work focuses on the identification of materials that exhibit a low OER overpotential with high stability and are either less expensive earth-abundant materials, or an amalgamation of the latter with a small amount of PGM oxide.[1, 10-14] Obviously, due to the extensive number of possible material candidates for the OER, a rapid screening method is required. Currently, OER studies involve the routine fabrication of electrodes from powders by depositing them onto conducting substrates by various methods, listed in Table 1, and the most popular of which is by drop-casting a dispersion of the metal oxide under investigation onto a glassy carbon, GC, electrode.

Table 1. 'Powder-to-electrode' methods used for OER studies

\begin{tabular}{|c|c|c|c|c|c|c|}
\hline WOC & $\eta_{10}(\mathrm{~V})$ & $\begin{array}{l}\text { Deposition } \\
\text { Method/ } \\
\text { Substrate }\end{array}$ & $\begin{array}{l}\text { Electrolyte } \\
\text { used for OER } \\
\text { studies }\end{array}$ & $\begin{array}{l}\text { Solvent } \\
\text { /polymer }\end{array}$ & $\begin{array}{l}\text { Annealing Temp/ } \\
\text { drying }\end{array}$ & Ref \\
\hline $\mathrm{Ni}(\mathrm{OH})_{2}$ & 0.36 & \multirow{2}{*}{$\begin{array}{l}\text { spray coating/ } \\
\text { Ni foam }\end{array}$} & \multirow[t]{2}{*}{$1 \mathrm{M} \mathrm{NaOH}$} & \multirow{2}{*}{$\begin{array}{l}\text { ethanol } \\
\text { /Nafion }\end{array}$} & \multirow[t]{2}{*}{ dry under $\mathrm{N}_{2}$ flow } & \multirow[t]{2}{*}{ [15] } \\
\hline $\mathrm{Fe}_{2} \mathrm{O}_{3}$ & 0.39 & & & & & \\
\hline $\mathrm{CO}_{3} \mathrm{O}_{4}$ & 0.5 & \multirow{5}{*}{$\begin{array}{l}\text { dropcast/ GC } \\
\text { discs. }\end{array}$} & \multirow[t]{5}{*}{$1 \mathrm{M} \mathrm{NaOH}$} & \multirow{5}{*}{$\begin{array}{l}\text { 2-propanol } \\
\text { /Nafion }\end{array}$} & \multirow{5}{*}{$\begin{array}{l}60^{\circ} \mathrm{C} \text { for } 10 \text { mins in } \\
\text { oven. }\end{array}$} & \multirow[t]{5}{*}{ [5] } \\
\hline $\mathrm{NiO}$ & 0.43 & & & & & \\
\hline $\mathrm{Mn}_{2} \mathrm{O}_{3}$ & 0.53 & & & & & \\
\hline $\mathrm{IrO}_{2}$ & 0.38 & & & & & \\
\hline $\mathrm{RuO}_{2}$ & 0.38 & & & & & \\
\hline $\mathrm{CO}_{3} \mathrm{O}_{4}$ & 0.53 & $\begin{array}{l}\text { dropcast/ } \\
\text { GC discs }\end{array}$ & $0.1 \mathrm{M} \mathrm{KOH}$ & $\begin{array}{l}\text { ethanol } \\
\text { /Nafion }\end{array}$ & dry in air. & [16] \\
\hline $\mathrm{IrO}_{2}$ & 0.45 & $\begin{array}{l}\text { dropcast/ GC } \\
\text { disc }\end{array}$ & $0.1 \mathrm{M} \mathrm{KOH}$ & $\begin{array}{l}\text { ethanol/cond } \\
\text { uctive } \\
\text { carbon and } \\
\text { Nafion }\end{array}$ & dry in air. & [17] \\
\hline $\mathrm{CO}_{3} \mathrm{O}_{4}$ & 0.47 & $\begin{array}{ll}\text { dropcast/ } & \mathrm{Au} \\
\text { discs } & \end{array}$ & $0.1 \mathrm{M} \mathrm{KOH}$ & ethanol & $\begin{array}{l}\text { dried at } 120{ }^{\circ} \mathrm{C} \text { for } \\
2 \text { hours in vacuum. }\end{array}$ & [18] \\
\hline
\end{tabular}




\begin{tabular}{|l|l|l|l|l|l|l|}
\hline $\begin{array}{l}\text { NiFe } \\
\text { LDH/ } \\
\text { CNT* }\end{array}$ & 0.26 & & $1 \mathrm{M} \mathrm{KOH}$ & $\begin{array}{l}\text { ethanol/ } \\
\text { Nafion }\end{array}$ & dry in air. & [19] \\
\hline
\end{tabular}

*LDH/CNT = Layered double hydroxide/carbon nanotube

The electrodes produced using these methods are usually not robust physically and result in poor electrochemical stability. In literature, this can be observed from the various stability studies (chronopotentiometry or multi-cycling) when a decrease in activity is observed over time, which is probably due to properties associated with the support material and/or the degrading of the active material therefore alternative support materials are sought after.[20,21] In addition, the usual casting/coating methods often use solvents, such as EtOH and 2-propanol, table 1, and require the addition of materials, such as CNTs and Nafion, to improve the conductivity of the film, which can influence the performance of the materials.[22-24] Another disadvantage associated with the usual 'powder to electrode' methods is the risk of contamination when using the same substrate to test various powder electrocatalyst candidates. Finally, in most cases, the underlying substrate, is often costly and needs to be re-used, thus rendering it infeasible to keep any prepared drop-cast electrode for any length of time.

In this paper we propose a simple, mechanical approach to fabricate electrodes from powders to test as OER catalysts, in which the electroactive material under test is mixed with PTFE powder and pressed into a thin layer on an underlying bed of Pt powder to yield a disc, which can then be used as an RDE. Herein, the electrochemical characteristics of a number of different metal oxide electrodes made using this method are compared with those made using the common drop-cast method and the results are reported below.

\section{Experimental Details}

\subsection{Materials}

The ruthenium (IV) oxide (99.9\%), nickel (II) oxide ( $<50 \mathrm{~nm}$ particle size, $99.8 \%)$, cobalt (II.III) oxide (< $50 \mathrm{~nm}$ particle size,99.5\%), poly(tetrafluoroethylene) (PTFE) powder ( $1 \mu \mathrm{m}$ particle size) and Nafion 117 solution were all obtained from Sigma Aldrich. The platinum (200 mesh, metals basis, 99.98\%) and silver (325 mesh, metals basis, 99.98\%) powders were obtained from Alfa Aesar and the $\mathrm{NaOH}$ pellets from Scientific and Chemical Supplies Itd. 


\subsection{Pressed Disc Fabrication}

In this work, a typical pressed disc electrode, containing a potential water oxidation powder catalyst, was prepared as follows: $300 \mathrm{mg}$ of the Pt powder were placed in an IR pellet press die (Specac) with a $4 \mathrm{~mm}$ internal diameter. The powder was tamped down by hand using the stainless steel IR die rod. Then, a powder mixture comprising of $0.9 \mathrm{mg}$ of the metal oxide powder catalyst under test, and $0.1 \mathrm{mg}$ of an inert binder, PTFE powder, were added to the die. After gentle tamping, a robust (catalyst/PTFE)/Pt composite disc was then fabricated by applying $2 \mathrm{~T}$ of pressure for $10 \mathrm{~s}$ to the (metal oxide/PTFE)/Pt using a hydraulic IR press; a schematic illustration of this process is illustrated in Fig. 1 (a). Pt powder was chosen as the backing material for our catalysts as it is: (i) easily pressed to obtain a physically robust underlying support conductor, (ii) commonly used as a substrate for OER and (iii) known to be an unexceptional as an OER catalyst, but stable as an electrode material for such work.[25-27]

Photographs of a typical pressed disc, with commercial $\mathrm{RuO}_{2}$ as the black, electro-active top layer are illustrated in Fig 1. (b) and (c). The SEM and EDX analysis of this disc are illustrated in Fig 1. (d) - (f). The EDX analysis shows that there is only a small amount of Pt on the surface of the electrode, Fig. $1(f)$, and mainly at the edge. In contrast, most of the surface of the electrode is made up of the pressed metal oxide powder (Ru La1, Fig. 1(e)). The pressed disc is then inserted into a RDE set-up (ALS co. Ltd, 012623), so as to allow its assessment as an electrocatalyst.

\subsection{Dropcast electrode fabrication}

The metal oxide ink dispersions used to dropcast onto the GC discs were prepared using an established procedure. ${ }^{6}$ Briefly, this involved placing $100 \mathrm{mg}$ of the relevant powder, $4 \mathrm{ml}$ of deionised water, $1 \mathrm{ml}$ of ethanol and $50 \mu \mathrm{l}$ of Nafion into a vial. The metal oxide ink dispersion was sonicated for 10 mins and then $45 \mu$ of the ink were dropcast onto a GC disc. The ink was dropcast every 5 mins onto the RDE disc until all $45 \mu \mathrm{l}$ of the ink were deposited onto the disc. The disc was allowed to dry in the oven at $60{ }^{\circ} \mathrm{C}$ between each deposition and then allowed to dry for 30 mins in the oven.

\subsection{Other methods}

Scanning Electron Microscopy (SEM) measurements were carried out using a FEI Quanta ${ }^{\mathrm{TM}} 250$ SEM with a spot size of $4 \mathrm{~mm}$, working distance of $10 \mathrm{~mm}$ and an accelerating voltage of $20 \mathrm{kV}$. Elemental mapping was carried out using the same instrument coupled to an EDX detector from Oxford Instruments. 


\subsection{Electrochemical methods}

All electrochemical measurements were conducted using a three electrode cell. The working electrode consisted of a pressed Pt or Ag disc with the active material, prepared as described in Section 2.1, or a drop-cast-coated commercial GC disc (ALS co. Ltd, 013338). In both cases, the disc electrodes were inserted into the RDE disc assembly (ALS co. Ltd) then screwed into the rotating disc set-up. All working electrodes had a diameter of $4 \mathrm{~mm}$ and had a mass loading of ca. $0.9 \mathrm{mg}$.

For all the OER measurements, the counter and reference electrodes were a graphite rod and $\mathrm{Hg} / \mathrm{HgO}$ electrode, respectively, the electrolyte was $1 \mathrm{M} \mathrm{NaOH}$ and the working electrode was spun at $1500 \mathrm{rpm}$. Linear Sweep Voltammetry (LSV) studies were conducted at a scan rate of $0.1 \mathrm{mV} / \mathrm{sec}$. Chronopotentiometric stability tests were run by applying a constant current density of $10 \mathrm{~mA} \mathrm{~cm}$. The solution resistance values, used to iR correct the LSV, were determined by Electrochemical Impedance Spectroscopy (EIS). The EIS measurements were conducted in the frequency range of $10000 \mathrm{~Hz}$ to $0.1 \mathrm{~Hz}$ in a non-Faradaic region. In this study, typical resistance values for all metal oxide electrodes were between 7-11 $\Omega$. Electrochemical surface area (ECSA) experiments were carried out by performing multiple $\mathrm{CV}$ experiments in a non-Faradaic region (typically in the $0-0.3 \mathrm{~V} \mathrm{vs} . \mathrm{Hg} / \mathrm{HgO}$ region) at various scan rates (typically $1-200 \mathrm{mV} \mathrm{s}^{-1}$ ).

\section{Results and Discussion}

\subsection{Pressed RDE vs. Dropcast RDE for OER using a variety of different metal oxides}

The LSV curves for the metal oxide, $\mathrm{RuO}_{2}, \mathrm{CO}_{3} \mathrm{O}_{4}$ and $\mathrm{NiO}$, electrodes prepared by the pressed $\mathrm{Pt}$ disc method and dropcast onto GC method are illustrated in Figs. 2(a-b). LSV analysis yielded overpotential values, $\eta_{10}$, at a current density of $10 \mathrm{~mA} \mathrm{~cm}^{-2}$, which are summarised in Table 2 , along with the ECSA data. In all cases the overpotential values for the pressed electrodes were found to be much lower than those found for the drop-cast GC electrodes, the main cause for which appears to be the much greater ECSA values of the pressed discs, compared to the GC electrodes, see table 2. Note that the $\eta_{10}$ data reported here, using the dropcast/GC technique, compares well with those reported by others ${ }^{6}$, using the same technique and metal oxides (see the literature values in parentheses in table 2). The superior activity observed for the Pt pressed discs is clearly not a synergistic enhancement between the underlying Pt metal and the active material. This can be observed from the LSV curves of the $\mathrm{RuO}_{2}$ on a pressed Pt disc and dropcast on a commercial Pt disc, Figure 2(a), as the $\mathrm{RuO}_{2} / \mathrm{Pt}$ commercial disc is shifted to more anodic potentials compared to the $\mathrm{RuO}_{2} / \mathrm{Pt}$ pressed disc. One should note that the enhancement in the NiO on the pressed Pt over dropcast on the GC can also be explained by the large increase in the ECSA of the NiO on the Pt 
pressed disc. From table 2, the ECSA of the $\mathrm{NiO}$ on the pressed $\mathrm{Pt}$ is $400 \mathrm{~cm}^{-2}$ while the same material on the $\mathrm{GC}$ disc is $1.6 \mathrm{~cm}^{-2}$. Additionally, the reusability of the electrodes are illustrated in Fig 2(a), as the activity of a $\mathrm{RuO}_{2} / \mathrm{Pt}$ pressed disc shows only a small decrease ( $\sim 0 \mathrm{mV}$ at $10 \mathrm{~mA} \mathrm{~cm}{ }^{-2}$ ) when kept in storage in air for four months.

Unlike the drop-cast GC method, the pressed disc method also created electrodes of great stability, as demonstrated by running chronopotentiograms at $10 \mathrm{~mA} \mathrm{~cm}{ }^{-2}$, Figs. 2 (c-d). The results of this work demonstrate that, as noted by others $[5,20,21,28]$, metal oxides drop-cast onto GC electrodes are not very robust physically, so that with prolonged oxygen evolution the metal oxide becomes less active. This effect is strikingly illustrated by the sharp upward turn in the chronopotentiograms observed for all the drop-cast GC electrodes tested, see Fig. 2(d), and particularly so for the GC NiO electrode, with no coating lasted $>2.5 \mathrm{~h}$. This sudden loss in activity observed for the metal oxides on the GC may be due to the passivation of the GC support, recently reported by Geiger et al., which makes our Pt pressed discs an even more attractive option.[20] In contrast, the pressed Pt discs showed no evidence of wear, even after $20 \mathrm{~h}$ of use, under identical experimental conditions, Fig. 2(c). Additionally, if required, the Pt metal can be easily recovered and re-used by cutting or polishing off the top 'electrocatalyst' layer. However, these electrodes are not that expensive, according to Johnson Matthey the current cost of Pt is \$33 per gram therefore a pressed Pt disc electrode would cost approximately $\$ 10$ each, if using $300 \mathrm{mg}$ of Pt for the underlying support.[29] Also, the objective for fabricating these pressed discs is that they can be initially used for a prolonged period due to their excellent stability, Fig. 2(c), then reused and retested to monitor the change in activity at a later date, Fig 2(a).

Table 2. Summary of OER results

\begin{tabular}{|c|c|c|c|c|}
\hline & \multicolumn{2}{|c|}{ Commercial powders on pressed Pt disc. } & \multicolumn{2}{c|}{ Commercial powders on commercial GC disc. } \\
\hline & $\eta(\mathrm{V})$ at $10 \mathrm{~mA} \mathrm{~cm}^{-2}$ & ECSA (cm $\left.{ }^{-2}\right)$ & $\eta(\mathrm{V})$ at $10 \mathrm{~mA} \mathrm{~cm}$ & ECSA (cm $\left.{ }^{-2}\right)$ \\
\hline $\mathrm{RuO}_{2}$ & 0.25 & 124 & $0.34(0.38)^{*}$ & 5 \\
\hline $\mathrm{Co}_{3} \mathrm{O}_{4}$ & 0.32 & 154 & $0.36(0.5)^{*}$ & 28 \\
\hline $\mathrm{NiO}$ & 0.30 & 400 & $0.8(0.43)^{*}$ & 1.6 \\
\hline
\end{tabular}

*Value in brackets are reported by others for the same commercial metal oxides on a GC disc.[5]

\subsection{Pressed RDE electrode fabrication: Using silver powder}

In order to demonstrate that the pressed electrodes can be fabricated using a less expensive underlying conducting substrate, the commercial $\mathrm{RuO}_{2}$ powder used earlier was again pressed into a 
RDE disc but this time using Ag powder as the conducting metal support, instead of Pt. The LSV curve and stability test for the $\mathrm{RuO}_{2}$ pressed on the Ag powder disc electrode, Fig. 2(e)-(f), were almost identical to those for the $\mathrm{RuO}_{2} / \mathrm{Pt}$ pressed electrodes. From the LSV curves of the $\mathrm{RuO}_{2} / \mathrm{Ag}$ pressed electrode the overpotential was determined to be $0.26 \mathrm{~V}$ at a current density of $10 \mathrm{~mA} \mathrm{~cm}^{-2}$. The LSV of the bare $\mathrm{Ag}$ disc is relatively flat, apart from the $\mathrm{Ag}$ to $\mathrm{AgO}$ peak at about $0.3 \mathrm{~V}$ vs OER overpotential, Fig. 2(e). The Ag/AgO oxidation peak doesn't influence the OER performance of the $\mathrm{RuO}_{2}$ as it is only a redox peak, much like that observed for the $\mathrm{Ni}(\mathrm{II}) / \mathrm{Ni}(\mathrm{III})$ redox peak when $\mathrm{Ni}$ metal foam supports are used for the OER. [15] Thus, using Ag as the backing material, instead of Pt, reduces the fabrication cost of the pressed discs. These findings are interesting as $\mathrm{Ag}$ substrates are used throughout the literature for numerous electrochemical applications including OER, biomolecule immobilisation and glucose sensing.[25, 30, 31]

\section{Conclusions}

A mechanical, solvent-free route to produce electrodes for the OER is presented. The results show that the pressed Pt disc method produces electrodes that exhibit superior OER performances in comparison to the usual dropcast method, on GC, for the same powder test metal oxide materials. This enhancement is most probably related to the increased electrochemical surface areas of the pressed disc electrodes over the dropcast GC ones. Other work shows that the cost of preparing the mechanical electrodes can be reduced markedly by using Ag as the underlying support material. This mechanical, solvent-free route for producing OER electrodes offers a new, simple route to electrode fabrication which will help in screening any new potential electrode materials for use in the OER and other reactions. In addition to being simple and fast and producing electrodes with high electrochemical surface areas, it also creates electrode discs which can be used again, unlike the more commonly employed drop-casting GC method.

Acknowledgements: We thank Nathan Wells and Aaron McNeil for help in recording the SEM.

\section{References}

[1] S. Cherevko, S. Geiger, O. Kasian, N. Kulyk, J.-P. Grote, A. Savan, B.R. Shrestha, S. Merzlikin, B. Breitbach, A. Ludwig, K.J.J. Mayrhofer, Oxygen and hydrogen evolution reactions on $\mathrm{Ru}, \mathrm{RuO}_{2}$, Ir, and $\mathrm{IrO}_{2}$ thin film electrodes in acidic and alkaline electrolytes: A comparative study on activity and stability, Catal. Today, 262 (2016) 170-180.

[2] M. Gong, H. Dai, A mini review of NiFe-based materials as highly active oxygen evolution reaction electrocatalysts, Nano Res., 8 (2015) 23-39.

[3] K. Zeng, D. Zhang, Recent progress in alkaline water electrolysis for hydrogen production and applications, Prog. Energy Combust. Sci., 36 (2010) 307-326.

[4] M. Görlin, J. Ferreira de Araújo, H. Schmies, D. Bernsmeier, S. Dresp, M. Gliech, Z. Jusys, P. Chernev, R. Kraehnert, H. Dau, P. Strasser, Tracking Catalyst Redox States and Reaction Dynamics in 
Ni-Fe Oxyhydroxide Oxygen Evolution Reaction Electrocatalysts: The Role of Catalyst Support and Electrolyte pH, J. Am. Chem. Soc., 139 (2017) 2070-2082.

[5] S. Jung, C.C.L. McCrory, I.M. Ferrer, J.C. Peters, T.F. Jaramillo, Benchmarking nanoparticulate metal oxide electrocatalysts for the alkaline water oxidation reaction, Journal of Materials Chemistry A, 4 (2016) 3068-3076.

[6] C.C.L. McCrory, S. Jung, I.M. Ferrer, S.M. Chatman, J.C. Peters, T.F. Jaramillo, Benchmarking Hydrogen Evolving Reaction and Oxygen Evolving Reaction Electrocatalysts for Solar Water Splitting Devices, J. Am. Chem. Soc., 137 (2015) 4347-4357.

[7] M.E.G. Lyons, R.L. Doyle, M.P. Browne, I.J. Godwin, A.A.S. Rovetta, Recent developments in electrochemical water oxidation, Current Opinion in Electrochemistry, 1 (2017) 40-45.

[8] M.E.G. Lyons, R.L. Doyle, D. Fernandez, I.J. Godwin, M.P. Browne, A. Rovetta, The mechanism and kinetics of electrochemical water oxidation at oxidized metal and metal oxide electrodes. Part 1. General considerations: A mini review, Electrochem. Commun., 45 (2014) 60-62.

[9] M.E.G. Lyons, R.L. Doyle, D. Fernandez, I.J. Godwin, M.P. Browne, A. Rovetta, The mechanism and kinetics of electrochemical water oxidation at oxidized metal and metal oxide electrodes. Part 2. The surfaquo group mechanism: A mini review, Electrochem. Commun., 45 (2014) 56-59.

[10] M.P. Browne, H. Nolan, G.S. Duesberg, P.E. Colavita, M.E.G. Lyons, Low Overpotential High Activity Mixed Manganese and Ruthenium Oxide Electrocatalysts for Oxygen Evolution Reaction in Alkaline Media, ACS Catalysis, 6 (2016) 2408-2415.

[11] M. Fu, Q. Jiao, Y. Zhao, Preparation of $\mathrm{NiFe}_{2} \mathrm{O}_{4}$ nanorod-graphene composites via an ionic liquid assisted one-step hydrothermal approach and their microwave absorbing properties, Journal of Materials Chemistry A, 1 (2013) 5577-5586.

[12] S. Klaus, Y. Cai, M.W. Louie, L. Trotochaud, A.T. Bell, Effects of Fe Electrolyte Impurities on $\mathrm{Ni}(\mathrm{OH})_{2} / \mathrm{NiOOH}$ Structure and Oxygen Evolution Activity, Journal of Physical Chemistry C, 119 (2015) 7243-7254.

[13] M.P. Browne, H. Nolan, B. Twamley, G.S. Duesberg, P.E. Colavita, M.E.G. Lyons, Thermally Prepared $\mathrm{Mn}_{2} \mathrm{O}_{3} / \mathrm{RuO}_{2} / \mathrm{Ru}$ Thin Films as Highly Active Catalysts for the Oxygen Evolution Reaction in Alkaline Media, ChemElectroChem, 3 (2016) 1847-1855.

[14] A.A.S. Rovetta, M.P. Browne, A. Harvey, I.J. Godwin, J.N. Coleman, M.E.G. Lyons, Cobalt hydroxide nanoflakes and their application as supercapacitors and oxygen evolution catalysts, Nanotechnology, 28 (2017) 375401.

[15] M.P. Browne, J.M. Vasconcelos, J. Coelho, M. O'Brien, A.A. Rovetta, E.K. McCarthy, H. Nolan, G.S. Duesberg, V. Nicolosi, P.E. Colavita, M.E.G. Lyons, Improving the performance of porous nickel foam for water oxidation using hydrothermally prepared $\mathrm{Ni}$ and Fe metal oxides, Sustainable Energy \& Fuels, 1 (2017) 207-216.

[16] Y. Liu, D.C. Higgins, J. Wu, M. Fowler, Z. Chen, Cubic spinel cobalt oxide/multi-walled carbon nanotube composites as an efficient bifunctionalelectrocatalyst for oxygen reaction, Electrochem. Commun., 34 (2013) 125-129.

[17] Y. Zhu, W. Zhou, Y. Chen, J. Yu, M. Liu, Z. Shao, A High-Performance Electrocatalyst for Oxygen Evolution Reaction: $\mathrm{LiCO}_{0.8} \mathrm{Fe}_{0.2} \mathrm{O}_{2}$, Adv. Mater., 27 (2015) 7150-7155.

[18] H. Tüysüz, Y.J. Hwang, S.B. Khan, A.M. Asiri, P. Yang, Mesoporous $\mathrm{Co}_{3} \mathrm{O}_{4}$ as an electrocatalyst for water oxidation, Nano Res., 6 (2013) 47-54.

[19] M. Gong, Y. Li, H. Wang, Y. Liang, J.Z. Wu, J. Zhou, J. Wang, T. Regier, F. Wei, H. Dai, An Advanced Ni-Fe Layered Double Hydroxide Electrocatalyst for Water Oxidation, J. Am. Chem. Soc., 135 (2013) 8452-8455.

[20] S. Geiger, O. Kasian, A.M. Mingers, S.S. Nicley, K. Haenen, K.J.J. Mayrhofer, S. Cherevko, Catalyst stability benchmarking for the oxygen evolution reaction - the importance of backing electrode material and dissolution in accelerated aging studies, ChemSusChem 10.1002/cssc.201701523.

[21] M.-R. Gao, X. Cao, Q. Gao, Y.-F. Xu, Y.-R. Zheng, J. Jiang, S.-H. Yu, Nitrogen-Doped Graphene Supported CoSe2 Nanobelt Composite Catalyst for Efficient Water Oxidation, ACS Nano, 8 (2014) 3970-3978. 
[22] X. Zhou, Z. Xia, Z. Zhang, Y. Ma, Y. Qu, One-step synthesis of multi-walled carbon nanotubes/ultra-thin $\mathrm{Ni}(\mathrm{OH})_{2}$ nanoplate composite as efficient catalysts for water oxidation, Journal of Materials Chemistry A, 2 (2014) 11799-11806.

[23] X. Lu, W.-L. Yim, B.H.R. Suryanto, C. Zhao, Electrocatalytic Oxygen Evolution at Surface-Oxidized Multiwall Carbon Nanotubes, J. Am. Chem. Soc., 137 (2015) 2901-2907.

[24] R.L. Doyle, M.E.G. Lyons, Redox and Oxygen Evolution Electrocatalytic Properties of Nafion and Single-Walled Carbon Nanotube/Hydrous Iron Oxide Composite Films, Electrocatalysis, 5 (2014) 114124.

[25] L.C. Seitz, T.J.P. Hersbach, D. Nordlund, T.F. Jaramillo, Enhancement Effect of Noble Metals on Manganese Oxide for the Oxygen Evolution Reaction, The Journal of Physical Chemistry Letters, 6 (2015) 4178-4183.

[26] T. Reier, M. Oezaslan, P. Strasser, Electrocatalytic Oxygen Evolution Reaction (OER) on Ru, Ir, and Pt Catalysts: A Comparative Study of Nanoparticles and Bulk Materials, ACS Catalysis, 2 (2012) 1765-1772.

[27] Y. Vlamidis, E. Scavetta, M. Gazzano, D. Tonelli, Iron vs Aluminum Based Layered Double Hydroxides as Water Splitting Catalysts, Electrochim. Acta, 188 (2016) 653-660.

[28] M. Gao, W. Sheng, Z. Zhuang, Q. Fang, S. Gu, J. Jiang, Y. Yan, Efficient Water Oxidation Using Nanostructured $\alpha$-Nickel-Hydroxide as an Electrocatalyst, J. Am. Chem. Soc., 136 (2014) 7077-7084.

[29] J. Matthey, October 2017, http://www.platinum.matthey.com/prices/price-charts.

[30] L. Shahriary, A.A. Athawale, Electrochemical deposition of silver/silver oxide on reduced graphene oxide for glucose sensing, J. Solid State Electrochem., 19 (2015) 2255-2263.

[31] X. Luo, A. Morrin, A.J. Killard, M.R. Smyth, Application of Nanoparticles in Electrochemical Sensors and Biosensors, Electroanalysis, 18 (2006) 319-326.

(a)

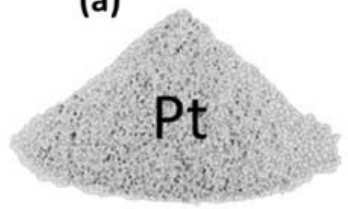

(i)

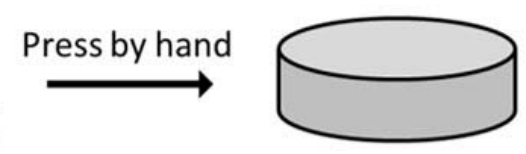

(ii)

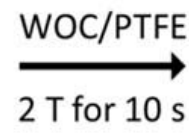

$2 \mathrm{~T}$ for $10 \mathrm{~s}$

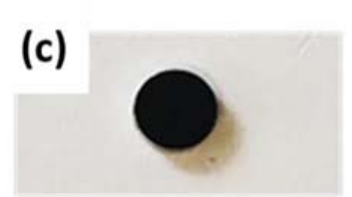

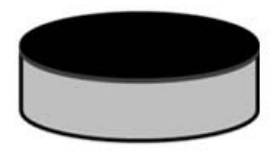

(iii)
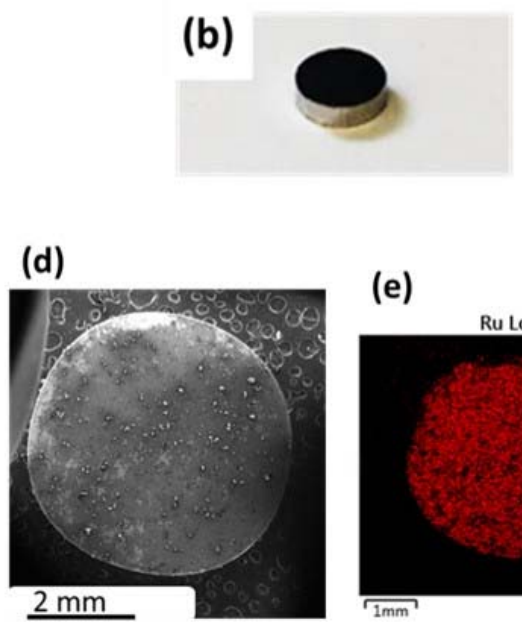

(e)

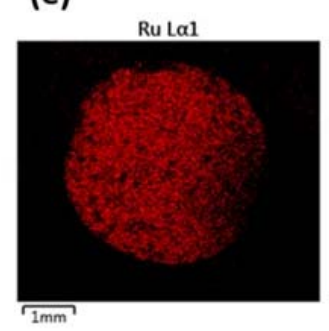

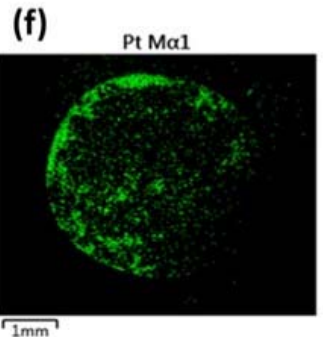

Fig. 1 (a) Schematic of the pressed disc fabrication process with (b) side and (c) top images of a typical pressed $\mathrm{RuO}_{2} / \mathrm{Pt}$ disc (d) SEM image of a pressed $\mathrm{RuO}_{2} / \mathrm{Pt}$ disc (e) $\mathrm{Ru} \mathrm{L} \alpha 1$ and (f) Pt M $\alpha 1$ EDX map of a pressed $\mathrm{RuO}_{2} / \mathrm{Pt}$ disc. 

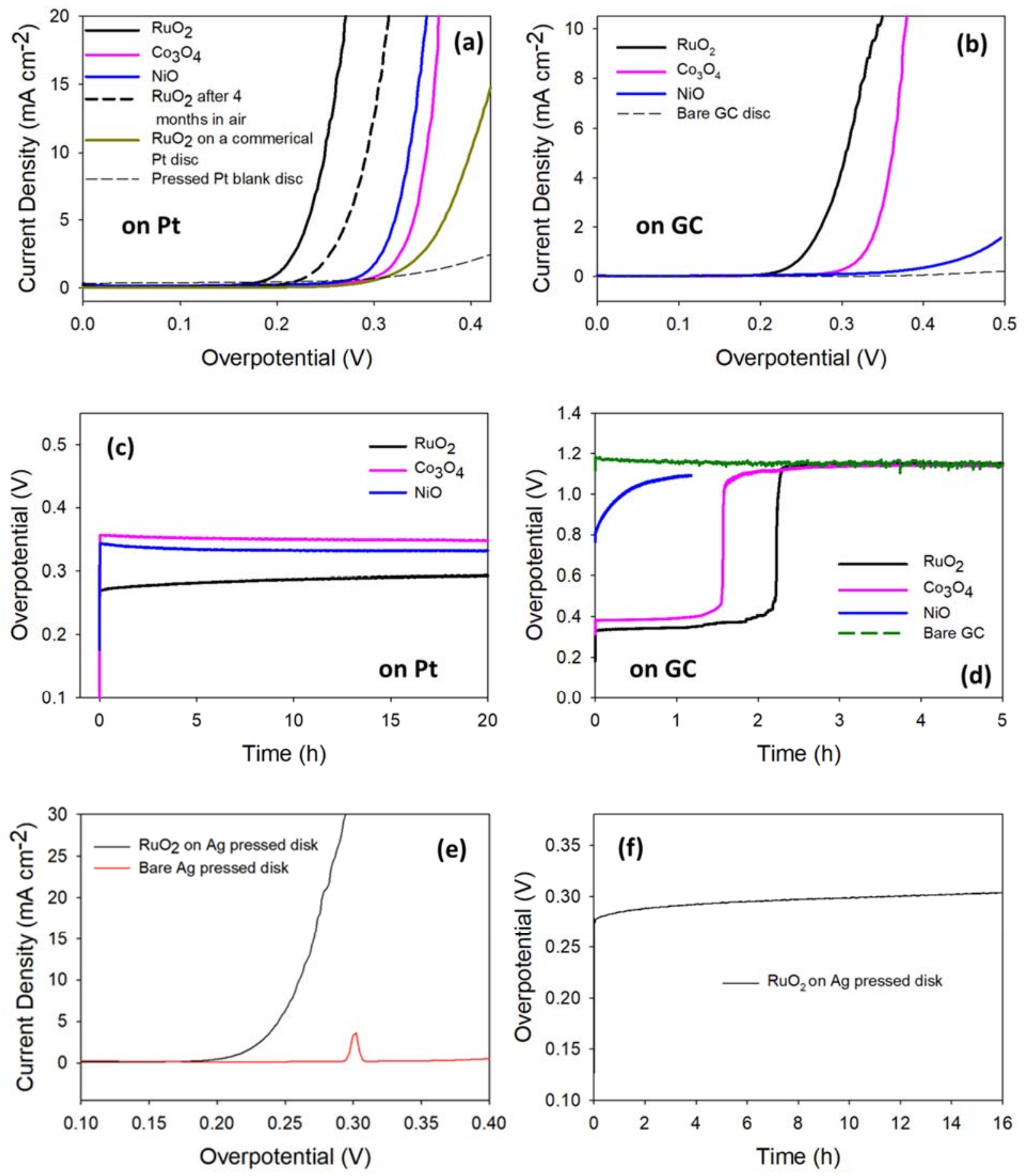

Fig. 2. LSV curves of the commercial $\mathrm{RuO}_{2}, \mathrm{CO}_{3} \mathrm{O}_{4}$ and $\mathrm{NiO}$ on (a) pressed Pt discs with $\mathrm{RuO}_{2} / \mathrm{Pt}$ after 4 months in air and $\mathrm{RuO}_{2}$ on a commercial Pt disc (b) GC discs. Stability tests for the commercial $\mathrm{RuO}_{2}$ $\mathrm{CO}_{3} \mathrm{O}_{4}$ and $\mathrm{NiO}$ on (c) pressed Pt discs (d) GC discs. (e) LSV curve of the commercial $\mathrm{RuO}_{2}$ on a pressed $\mathrm{Ag}$ disc and (f) Stability test of the commercial $\mathrm{RuO}_{2}$ on a pressed $\mathrm{Ag}$ disc. 